\title{
MODELLING THE DYNAMICS OF THE ADEQUACY OF BANK'S REGULATORY CAPITAL
}

\author{
Leonid Katranzhy' ${ }^{1}$, Oleksandr Podskrebko ${ }^{2}$, Vitaliy Krasko ${ }^{3}$ \\ State Institution of Higher Education "Donetsk National Technical University", Ukraine
}

\begin{abstract}
The purpose of the article is to develop scientific and methodological recommendations for modelling the dynamics of the level of capital adequacy for ensuring the financial balance of the bank, sufficient controllability and increasing the efficiency of its activities. The article explores peculiarities of banking regulation and supervision in the process of capital formation. It is shown that the issue of formation of capital by banking institutions is actualized in the context of management reform and target tasks of the development of the banking industry of Ukraine. Given the state of the banking services market and its development trends, the unsettled problem of the capitalization of banks, it becomes important to improve the mechanism of capital formation. In order to improve the efficiency of bank regulation and management of capital formation, recommendations are proposed for modelling the dynamics of the adequacy of regulatory capital on the basis of determining the forecast values of its components. Research methodology: the feasibility of using predictive models with the use of artificial neural networks is substantiated. In contrast to the classic trend, discussed in the article, the models with the architecture of the multilayer perceptron proved to be the most adequate and accurate. In addition to a point forecast of the dynamics of regulatory capital, the overall risk and the amount of the net foreign exchange position, their pessimistic and optimistic forecasts were constructed. The author's proposals are formalized by appropriate calculation algorithms. Modelling the dynamics of the adequacy of regulatory capital and its components in practice will allow more efficiently manage systemic and individual banking risks.
\end{abstract}

Key words: bank's regulatory capital, capital ratios, adequacy of regulatory capital, forecasting, neural networks, modelling.

\section{JEL Classification: G21, G28}

\section{Introduction}

Solving many of the problems facing the Ukrainian economy, namely, overcoming the socio-economic crisis, ensuring economic growth, increasing the participation of banks in the investment process, and increasing lending depends to a certain extent on the effective functioning of the banking system and the level of its stability. It is clear that at the present stage, only those banks that can quickly adapt to the trends of crisis recovery, to take precautionary measures, in advance anticipating the possible consequences of both their own risky activities and the negative impact of systemic risks will survive.

The specific structure of capital with a high share of debt burden inherent in banks objectively determines the need for capital formation in accordance with financial risks. Of course, not all risk assets can be fully covered. This is only a matter of determining the minimum adequate amount, that is, the proportion of the total risk borne by the bank owners. At the same time, each separate banking institution should have available capital sufficient to cover possible losses, support for solvency and financial independence.

From these positions, modelling the dynamics of the adequacy of regulatory capital of the bank as one of the main regulatory requirements put forward by banks on the part of the state in the person of the regulator the National Bank of Ukraine (hereinafter - the NBU) and taking into account the importance of the banking sector's role in the development of the financial system and national economy in general, is a topical issue of research.

\footnotetext{
Corresponding author:

${ }^{1}$ Department of Accounting, Finance and Economic Security, State Institution of Higher Education "Donetsk National Technical University”.

E-mail: leonid.katranzhy@donntu.edu.ua

${ }^{2}$ Department of Economic Cybernetics and Further Mathematics, State Institution of Higher Education "Donetsk National Technical University".

E-mail: alexandr.podskrebko@gmail.com

${ }^{3}$ Department of Economic Cybernetics and Further Mathematics, State Institution of Higher Education "Donetsk National Technical University".

E-mail: vitaliy.krasko@donntu.edu.ua
} 


\section{Review of the literature}

The problem of the formation of bank capital due to its theoretical importance and practical significance is in the area of constant attention of scientists. The issue of the factors affecting the formation of the capital structure of banking institutions and the transformation of banking resources, ensuring a higher level of capitalization of banks and the banking system as a whole, features of the functioning of banks with foreign capital are highlighted in the work of foreign and domestic scientists: R. Gropp, 2009, O. Ikpefan, 2012, T. Koch, 2003, M. Octavia, 2008, J. Sinkey, 2002, M. Alekseienko, 2002, A. Vozhzhov, 2007, Zh. Dovhan, 2008, R. Kornyliuk, 2012, S. Reverchuk, 2011 , and others.

Given the exclusive role of administrative and indicative forms of state regulation of banking activity, of particular interest is the research in the part of the influence imposed by the regulator of prudential regulations and organization of banking supervision over the capital formation, among which are the work of the following researchers: D. Gale, 2010, H. Greuning, 2009, D. Hancock, 2006, V. Kovalenko, 2013, S. Naumenkova, 2015, O. Khabiuk, 2008.

The urgency and importance of issues regarding the application of mathematical methods for solving the problems of management of the formation of bank capital determined the purpose of the study.

The purpose of this paper is to develop scientific and methodological recommendations for modelling the dynamics of the level of capital adequacy for ensuring the financial balance of a banking institution, sufficient controllability and increasing the efficiency of its activities.

\section{Statement of the main material}

Despite the fact that in Ukraine, in accordance with the current legislation (Pro zatverdzhennia Instruktsii pro poriadok rehuliuvannia diialnosti bankiv v Ukraini), a system of prudential regulations of capital (minimum regulatory capital ratio - $\mathrm{H} 1$, regulatory capital adequacy ratio - $\mathrm{H} 2$, core capital adequacy ratio - $\mathrm{H} 3$ ) and additional requirements in the form of the formation of buffers of capital (capital reserve (conservation) buffer, countercyclical buffer, system importance buffer) have been established for banks, the choice as an object of modelling the indicator of regulatory capital adequacy in this the study is not accidental due to a number of reasons:

1. Currently, banks are actually calculated from the whole set of indicators, only two: the minimum regulatory capital ratio and the regulatory capital adequacy ratio. Introduction to the practice of indicative banking regulation of the core capital adequacy ratio is scheduled from 01.01.2019, and capital buffers - from 01.01.2020.

In addition, the calculation of the regulatory capital adequacy indicator based on the recommendations of the Basel Committee on Banking Supervision for regulatory purposes is a common practice in many countries.

2. $\mathrm{H} 2$ ratio has a certain generalizing character: when it is calculated, the actual values of the regulatory capital are used, that is, the actual value of $\mathrm{H} 1$ and the total amount of risk (the sum of assets and off-balance sheet liabilities of the bank, weighted by the corresponding coefficients of credit risk). In turn, regulatory capital is the basis for calculating ratios: the maximum size of credit risk per one counterparty - $\mathrm{H} 7$, large credit risks - $\mathrm{H} 8$, the maximum size of credit risk for transactions with bankrelated individuals - H9, fixed capital as a component of the regulatory capital - to calculate H3. Capital buffers are determined as a percentage of the total risk.

3. Although compliance with the regulatory capital adequacy ratio is not a complete guarantee of the timeliness and completeness of settlement of obligations, for depositors and creditors, the value of this indicator is rather informative, since the larger its size, the lower the share of risk they assume. The actual values of the $\mathrm{H} 2$ ratio indicate the bank's ability to withstand crisis situations to some extent.

Proceeding from the theory of fiduciary duties, the growth of capital adequacy to potential risks can be considered as a signal that positively affects the level of trust in the bank.

4. The $\mathrm{H} 2$ ratio has a significant impact on capital decision-making. First, as well as any economic ratios and requirements set by the NBU, this ratio is mandatory. Second, the bank is forbidden to pay dividends or to distribute capital in any form, if this leads to a breach of the regulatory capital adequacy ratio. Thirdly, the possibility of expanding the activities of a banking institution is limited to the actual value of this indicator (the higher the value of the ratio of $\mathrm{H} 2$, the greater margin for expansion of banking activity).

5. The banks' compliance with the regulatory capital adequacy ratio, among other things, allows, provided that the financial and credit institution is unable to restore its solvency, ensuring an acceptable level of bank failures, increasing the stability of the functioning of the banking system.

In the generalized form, the procedure for calculating the regulatory capital adequacy ratio is as follows (1):

$$
H 2=\frac{P K}{A_{P}+C_{B I}} \cdot 100 \%,
$$

where $P K$ - bank's regulatory capital;

$A_{p}$ - assets and certain off-balance-sheet instruments, reduced by the amount of established reserves for active operations, by the amount of collateral for an unconditional obligation or cash in the form of a pledge of property rights, by the amount to an estimate, by the amount of non-issued bonds of an internal government loan and weighted by the appropriate credit risk factor depending on the risk group to which the asset belongs; 
$C_{\varepsilon n}$ - the aggregate amount of the bank's net foreign exchange position for all foreign currencies and bank metals.

Modelling the dynamics or predicting the adequacy of the regulatory capital of a banking institution is a complex and labour-intensive process that involves forecasting key performance indicators of the bank, namely, regulatory capital $(P K)$, risk-weighted assets $\left(A_{p}\right)$, amount of net foreign exchange position $\left(C_{B n}\right)$, and includes: time series analysis to identify its main components, such as trend, seasonality (cyclicity), residual (random) component. In order to improve the quality and reliability of the forecast, it is expedient to use not one model, but several, and compare them among themselves, estimating the forecast errors for each model. In this study, the trend models (linear and third-order hyperbolic) and the neural network (model of multilayer perceptron), in which neurons make the transformation of the input signals into output by the ratio (2) are used to predict the change in the adequacy of the regulatory capital of the bank (A. Matviichuk, 2011). The expediency of choosing these models was due to a rather high value of the indicator of the determination coefficient $\left(R^{2}>0,8\right)$. Based on indicators of informational suitability and assessment of the accuracy of the proposed models, the best of the models was identified.

$$
y=\vartheta\left(\sum_{i=1}^{n} w_{i} \cdot x_{i}+b\right),
$$

where $y$ - output signal of a neuron;

$n$ - number of inputs of this neuron;

$x_{i}$ - the $i$-th input signal of the neuron;

$w_{i}$ - the weight of the $i$-th input of the neuron;

$b$ - adder bias parameter;

$\vartheta(\cdot)$ - neuron activation function.

Fig. 1 shows the dynamics of changes in the regulatory capital of one of the Ukrainian banks for 1.5 years.

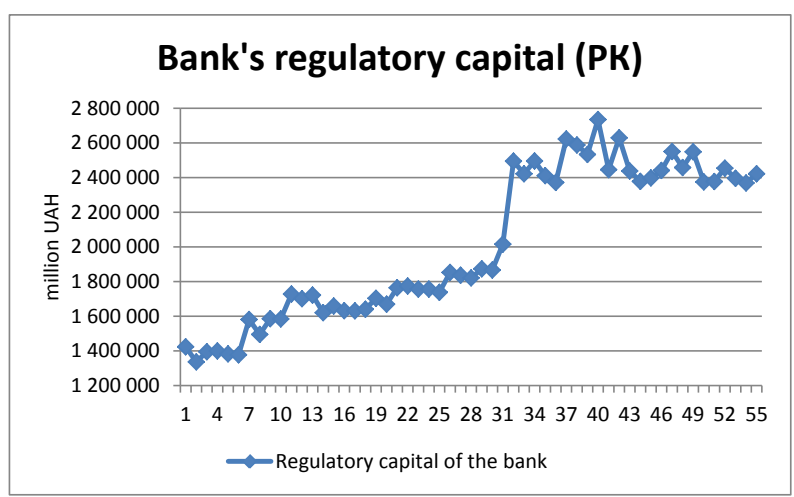

Fig. 1. Dynamics of Regulatory capital of the bank

To construct the model series of the proposed trend models, the functional of MS Excel for the model of multilayer perceptron was used - Statistica.
Fig. 2 shows the change in the regulatory capital of the banking institution and the model characteristics of the linear and polynomial trend models, as well as the dynamics of regulatory capital, which is described by the model of a multilayer perceptron.

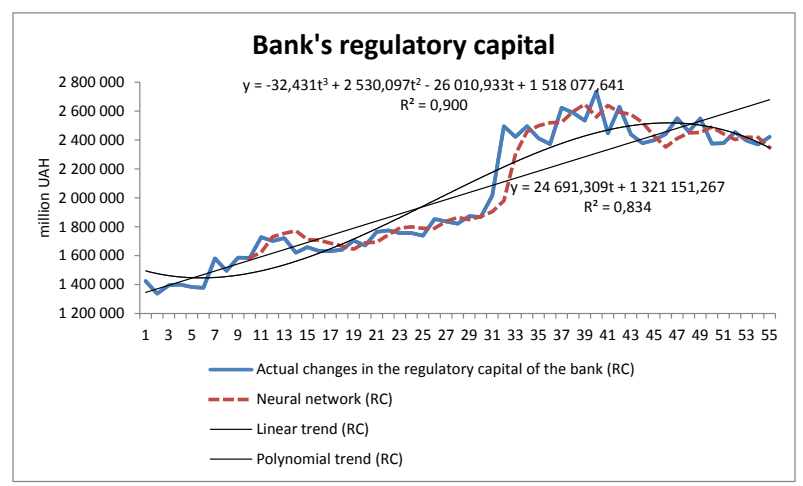

Fig. 2. Changes in the regulatory capital of the bank, which are described by trend models and the model of a multilayer perceptron

An important task of forecasting is to determine the characteristics of the quality of the proposed models, one of the criteria of which is the informational suitability of the econometric model, that is, how validly the model chosen for forecasting explains the retrospective of the investigated changes in regulatory capital. As the estimated characteristic of the a priori quality of the forecast model, it is expedient to use the estimated values of the determination coefficient (O. Plastun, 2014) (3).

$$
R^{2}=\frac{\sum_{t=1}^{n}\left(\hat{y}_{t}-\bar{y}\right)^{2}}{\sum_{t=1}^{n}\left(y_{t}-\bar{y}\right)^{2}},
$$

where $y_{t}$ - the actual value of the time series;

$\hat{y}_{t}-$ model values constructed according to the estimated parameters;

$\bar{y}$ - selective mean value.

Table 1 summarizes the values of the determination coefficient for the above models, which describe the dynamics of the indicator of regulatory capital of the bank.

Table 1

The value of the determination coefficient of the dynamics of regulatory capital of the bank

\begin{tabular}{|c|c|c|}
\hline \multicolumn{3}{|c|}{ Determination coefficient $\left(R^{2}\right)$, p. units } \\
\hline Linear trend & Polynomial trend & Neural network \\
\hline 0,834 & 0,9 & 0,911 \\
\hline
\end{tabular}

Thus, each of the proposed models describes the output time series at an adequate level $\left(R^{2}>0,8\right)$. The most appropriate model among the considered is the model of multilayer perceptron, the determination coefficient of which is $91.1 \%$. 
In addition to assessing the informational suitability of models, it is expedient to evaluate their accuracy. In the statistical analysis of time series, there is a sufficiently wide list of characteristics of the accuracy of models. In order to avoid contradictions in the conclusions that may arise due to the use of a number of indicators, for the evaluation of the accuracy of the proposed models, one indicator should be used throughout the analysis process, namely, we will use the average approximation error - A (3). The lower the value obtained for this indicator, the higher the accuracy of the model. It should be noted that at $\mathrm{A}<5 \%$ the accuracy of the model is considered high (O. Cherniak, P. Zakharchenko, 2011).

$$
A=\frac{1}{n} \sum_{t=1}^{n} \frac{\left|e_{t}\right|}{y_{t}}=\frac{1}{n} \sum_{t=1}^{n} \frac{\left|y_{t}-\hat{y}_{t}\right|}{y_{t}},
$$

where $n$ - number of units in the aggregate;

$e_{t}-$ residual sum of squares.

Table 2 presents the estimated values of average approximation error for each of the three models.

Table 2

The value of the average approximation error of models of the dynamics of regulatory capital of the bank

\begin{tabular}{|c|c|c|}
\hline \multicolumn{3}{|c|}{ Average approximation error (A), \% } \\
\hline Linear trend & Polynomial trend & Neural network \\
\hline 6,58 & 5,67 & 3,6 \\
\hline
\end{tabular}

Thus, the model of a multilayer perceptron, the average error of approximation of which was $3.6 \%$, was the best by the criterion of accuracy.

Table 3 shows the forecasted values of the regulatory capital of the bank (point forecast) with a depth of nine periods (quarter).

Table 3

Forecasted values of the bank's regulatory capital, thousand UAH

\begin{tabular}{|c|c|c|c|}
\hline Period & Linear trend & Polynomial trend & Neural network \\
\hline 56 & 2703864,6 & 2300447,1 & 2334302,5 \\
\hline 57 & 2728555,9 & 2249745,4 & 2331278,5 \\
\hline 58 & 2753247,2 & 2193012,6 & 2318402,9 \\
\hline 59 & 2777938,5 & 2130053,9 & 2311312,0 \\
\hline 60 & 2802629,8 & 2060674,9 & 2296867,1 \\
\hline 61 & 2827321,1 & 1984680,9 & 2287072,1 \\
\hline 62 & 2852012,4 & 1901877,3 & 2281247,7 \\
\hline 63 & 2876703,7 & 1812069,6 & 2274888,7 \\
\hline 64 & 2901395,0 & 1715063,2 & 2269772,6 \\
\hline
\end{tabular}

Fig. 3 graphically depicts changes in the regulatory capital of the bank, that is, the output time series, taking into account the projected values.

Equally important is the calculation of the confidence interval (interval forecast), which defines the limit

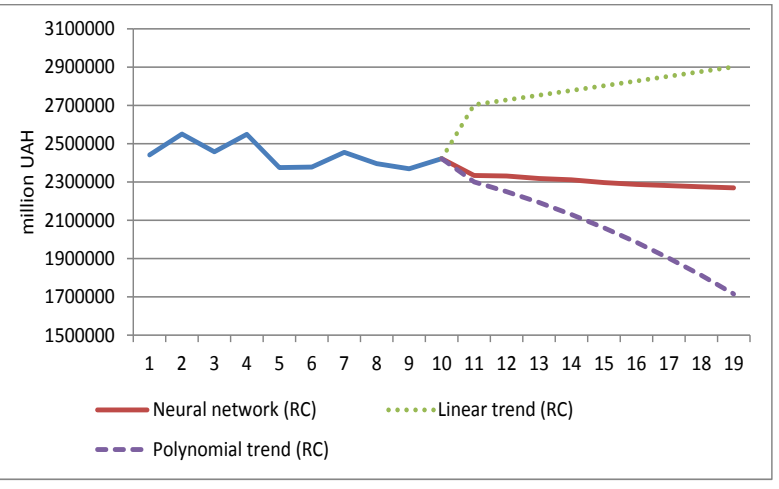

Fig. 3. Changes in the bank's regulatory capital taking into account the projected values with a depth of nine periods

values of the level of a series with a given confidence probability $\alpha$.

Fig. 4 shows the point and interval forecasts of the value of regulatory capital, constructed using a multilayer perceptron.

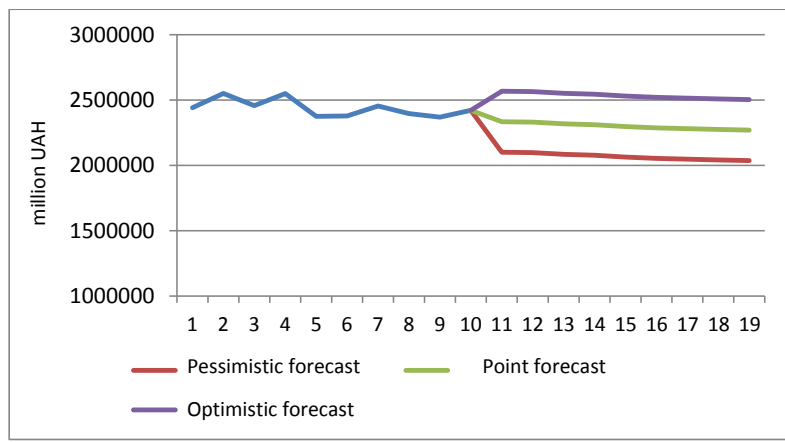

Fig. 4. Point and interval forecasts of the value of regulatory capital, constructed using a multilayer perceptron

Thus, we obtained an adequate model that characterizes the dynamics of the bank's regulatory capital, with the help of which the point and interval forecasts (interval width $\pm 10.1 \%$ ) of changes in its values with the depth of the forecast in 9 periods or a quarter are calculated, which makes it possible to estimate the level of coverage of negative effects of the various risks that banks assume in the course of their activities.

To obtain the projected value of the regulatory capital adequacy ratio $\mathrm{H} 2$ (1), similarly, it is necessary to calculate the forecasted values for the forthcoming quarter for risk-weighted assets $\left(A_{p}\right)$ and the aggregate amount of the net foreign exchange position $\left(C_{\theta n}\right)$ for all foreign currencies and banking metals.

Fig. 5 shows the dynamics of the $A_{p}$ indicator, the model characteristics of the linear and polynomial trend models, and the risk-weighted assets' changes described by the multilayer perceptron model.

The combined data of the values of the determination coefficient and the average approximation error of individual models of the overall risk dynamics $\left(A_{p}\right)$ of the bank are presented in Table 4 . 


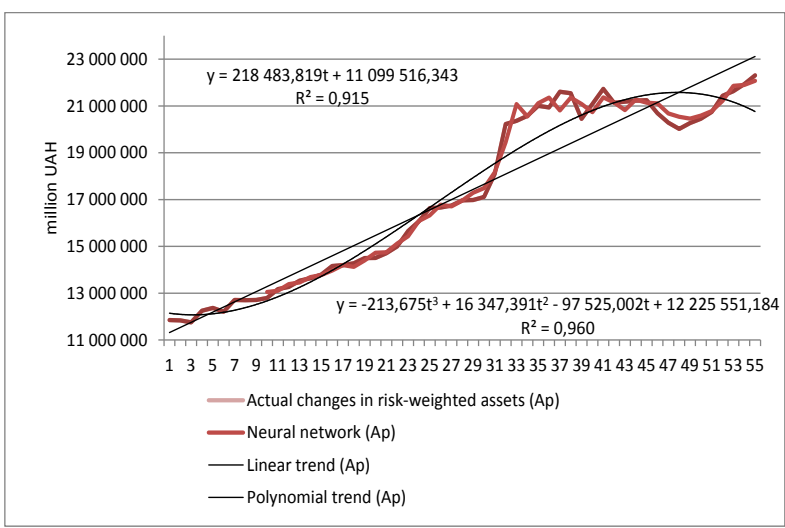

Fig. 5. Bank risk-weighted assets, which are described by trend models and multilayer perceptron model

Table 4

The value of the determination coefficient and the average approximation error of dynamic models of risk-weighted assets of the bank

\begin{tabular}{|c|c|c|}
\hline Linear trend & Polynomial trend & Neural network \\
\hline \multicolumn{3}{|c|}{ Determination coefficient $\left(R^{2}\right)$, p. units } \\
\hline 0,915 & 0,96 & 0,99 \\
\hline \multicolumn{3}{|c|}{ Average approximation error (A), \% } \\
\hline 4,5 & 3,11 & 1,18 \\
\hline
\end{tabular}

The most adequate model that characterizes the dynamics of $A_{p}$ is the model of a multilayer perceptron with a determination coefficient of $99 \%$ and average approximation error of $1.18 \%$.

Table 5 presents the forecast values (point forecast) of risk-weighted assets $\left(A_{p}\right)$ with a depth of 9 periods, obtained on the basis of the above models.

Table 5

Predicted values of bank risk-weighted assets, thousand UAH

\begin{tabular}{|c|c|c|c|}
\hline Period & Linear trend & Polynomial trend & Neural network \\
\hline 56 & 1709080 & 2334302,467 & 2959525 \\
\hline 57 & 1706056 & 2331278,53 & 2956501 \\
\hline 58 & 1693180 & 2318402,904 & 2943626 \\
\hline 59 & 1686089 & 2311312,037 & 2936535 \\
\hline 60 & 1671644 & 2296867,057 & 2922090 \\
\hline 61 & 1661849 & 2287072,06 & 2912295 \\
\hline 62 & 1656025 & 2281247,746 & 2906470 \\
\hline 63 & 1649666 & 2274888,74 & 2900111 \\
\hline 64 & 1644550 & 2269772,623 & 2894995 \\
\hline
\end{tabular}

Fig. 6 graphically depicts the dynamics of overall risk of the bank taking into account the projected values $A_{p}$.

Construction with a sufficient level of adequacy and accuracy of the dynamics model of risk-weighted assets (overall risk) of the bank based on the neural network allowed calculating the point and interval forecasts (interval width $\pm 15.4 \%$ ) - Fig. 7 .

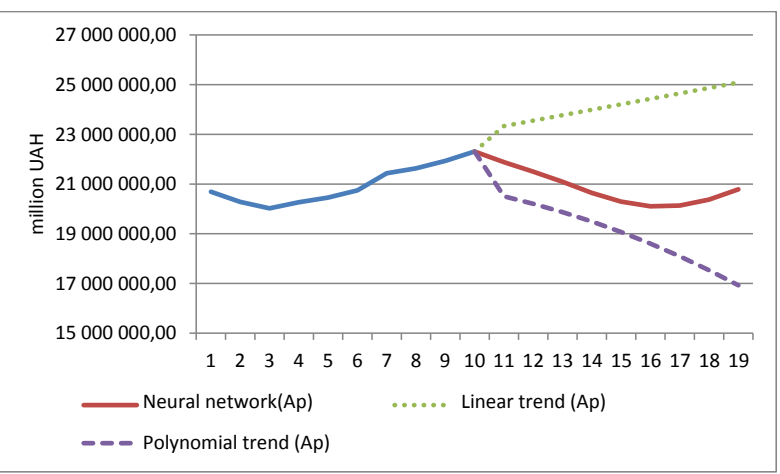

Fig. 6. Changes in bank risk-weighted assets taking into account the projected values obtained with a depth of nine periods

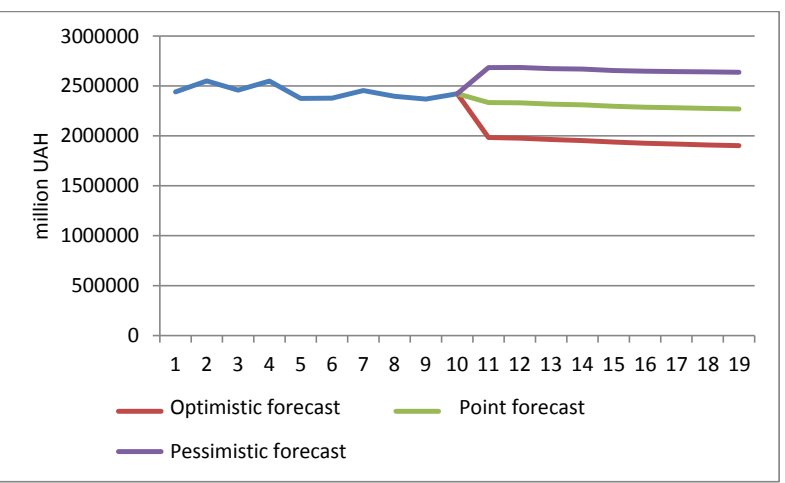

Fig. 7. Point and interval forecasts of the bank risk-weighted assets constructed using multilayer perceptron

The next step in determining the forecast value of the $\mathrm{H} 2$ ratio is to forecast the aggregate amount of the bank's net foreign exchange position on all foreign currencies and banking metals $\left(C_{6 n}\right)$, the dynamics and model characteristics of which are presented in Fig. 8.

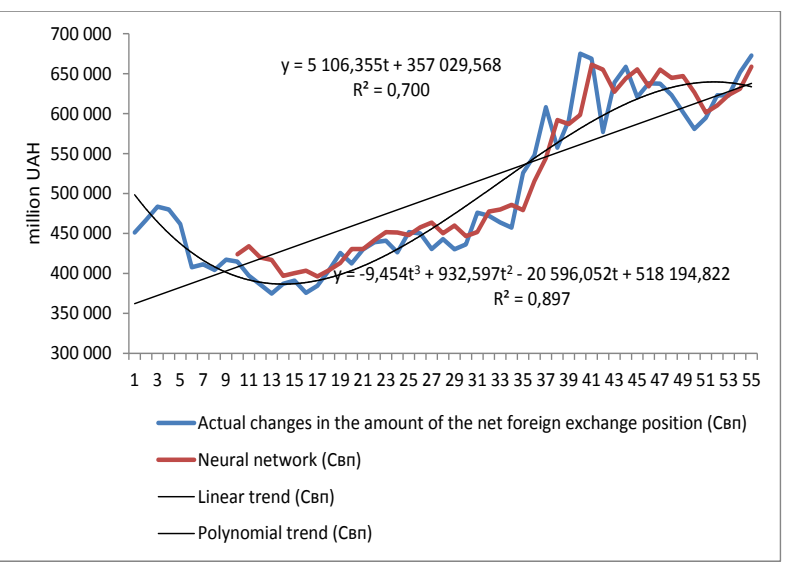

Fig. 8. Changes in the amount of the bank's net foreign exchange position, which are described by trend models and multilayer perceptron model

Indicators of information and prognostic suitability of the proposed models for $C_{8 n}$ are presented in Table 6 .

As can be seen from Table 6, the model of a multilayer perceptron is also the best model by information and prognostic suitability parameters. 
Table 6

The value of the determination coefficient and the average approximation error of dynamic models of the bank's net foreign exchange position

\begin{tabular}{|c|c|c|}
\hline Linear trend & Polynomial trend & Neural network \\
\hline \multicolumn{3}{|c|}{ Determination coefficient $\left(R^{2}\right)$, p. units } \\
\hline 0,7 & 0,897 & 0,923 \\
\hline \multicolumn{3}{|c|}{ Average approximation error (A), \% } \\
\hline 9,17 & 4,59 & 4,32 \\
\hline
\end{tabular}

Table 7 represents the forecast value (point forecast) of the net foreign exchange position $\left(C_{8 n}\right)$ amount with a depth of 9 periods, calculated using the above three models.

Table 7

Forecast values of the amount of the net foreign exchange position, thousand UAH

\begin{tabular}{|c|c|c|c|}
\hline Period & Linear trend & Polynomial trend & Neural network \\
\hline 56 & 669424,2 & 642985,448 & 629166,438 \\
\hline 57 & 678190,9 & 648091,803 & 623412,889 \\
\hline 58 & 689228,2 & 653198,158 & 616291,266 \\
\hline 59 & 692650,3 & 658304,513 & 607744,845 \\
\hline 60 & 703351,1 & 663410,868 & 597716,902 \\
\hline 61 & 709434,8 & 668517,223 & 586150,713 \\
\hline 62 & 718119,5 & 673623,578 & 572989,554 \\
\hline 63 & 725501,9 & 678729,933 & 558176,701 \\
\hline 64 & 734401,2 & 683836,288 & 541655,43 \\
\hline
\end{tabular}

Fig. 9 shows the dynamics of the $C_{6 n}$ based on the predicted values obtained.

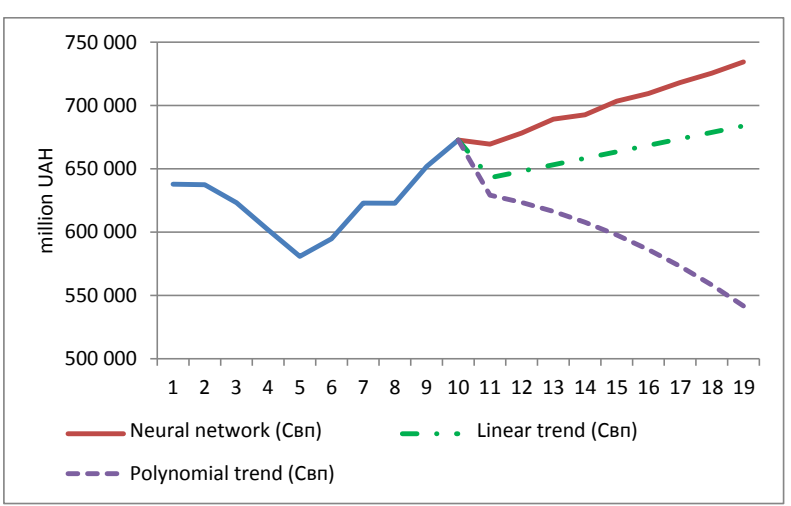

Fig. 9. Dynamics of the amount of the bank's net foreign exchange position taking into account the received forecast values with a depth of nine periods

Using artificial neural network, which characterizes the dynamics of the total amount of the bank's net foreign exchange position, point and interval forecasts were calculated (interval width $\pm 2.6 \%$ ) - Fig. 10 .

By carrying out modelling of three main components of the regulatory capital adequacy indicator, it is possible to obtain its forecast data in accordance with formula (1).

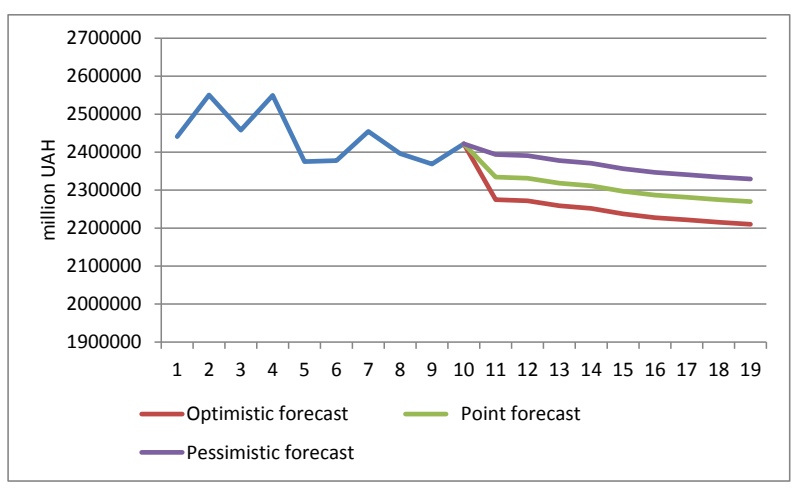

Fig. 10. Point and interval forecasts of the total amount of the bank's net foreign exchange position, built with the help of multilayer perceptron

Fig. 11 shows the dynamics of the change of $\mathrm{H} 2$ taking into account the forecasted values of regulatory capital, risk-weighted assets, and the amount of the bank's net foreign exchange position.

As can be seen from Fig. 11, the forecast of the dynamics of regulatory capital adequacy indicates a rather high overall risk of the banking institution and a small potential for increasing the volume of operations, given the increasing requirements of the NBU (gradual increase in the minimum size of regulatory capital to 500 million UAH from 11 July 2024, introduction the core capital adequacy ratio $(\mathrm{H} 3 \geq 7 \%)$ from 1 January 2019 , capital reserve (conservation) buffer from $0.625 \%$ from 1 January 2020 to $2.5 \%$ from 1 January 2023, countercyclical buffer from 1 January 2020 in the range of 0 to $2.5 \%$ depending on the lending activity of the bank and taking into account credit risks).

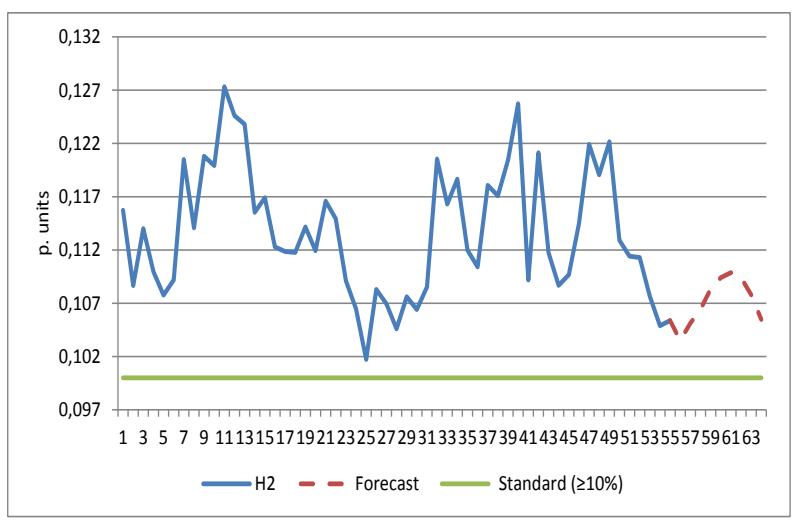

Fig. 11. Dynamics of the forecasted value of regulatory capital adequacy

Unfortunately, the problem of insufficient capitalization is widespread for a large number of functioning banks in Ukraine. In order to solve it, in our opinion, it is necessary to attract additional equity capital, to develop plans to increase the capitalization of banks with the use of additional sources, to implement cost optimization measures, to introduce advanced risk management approaches, to stimulate banks to reinvest 
profits through changes in taxation (introduction of differentiated rates of income tax that is consumed and capitalized), to further adapt the national banking standards to international requirements, ensuring transparency of capital formation, protection of investors and so on.

\section{Conclusions}

In the course of the research, a number of varied econometric models were developed for the dynamics of the adequacy indicator of the regulatory capital of the bank and its components: regulatory capital, total risk level (risk-weighted assets), and the amount of the bank's net foreign exchange position.
Based on the analysis, an adequate model has been substantiated and obtained that allows forecasting the value of $\mathrm{H} 2$. It was a neural model built with the help of a multilayer perceptron.

The importance of determining the dynamics of regulatory capital adequacy is conditioned as by the bank's internal needs associated with improving the risk management efficiency, making decisions on the formation of capital and its use, so by the needs of the regulator in the context of ensuring the reliability of the functioning of the banking system. In addition, the use of the proposed recommendations has prospects for choosing the regime of prudential regulation of banks, a reasonable determination of the size of capital buffers, including systemically important banks.

\section{References:}

Gropp, R. Heider, F. (2009). The determinants of bank capital structure: Working paper series, 52.

Dr Ikpefan, O. A. (2012). The impact of Bank capitalization in the Performance of Nigerian banking Industry (1986-2006). The Journal of Commerce. 4 (11), 24-39.

Koch, Timothy W. (2003). Bank management. Cincinnati, Ohio: South-Western. 888.

Octavia, M., Brown, R. (2008). Determinants of bank capital structure in developing countries: regulatory capital requirement versus the standard determinants of capital structure. Department of Finance the University of Melbourne, 35.

Sinkey, Josef F. (2002). Commercial Bank Financial Management in the Financial-services Industry. Prentice Hall. 696.

Alekseienko, M. D. (2002). Kapital banku: pytannia teorii i praktyky: [monohrafiia]. K.: KNEU. 276.

Vozhzhov, A. P. (2007). Pryroda y mekhanyzm transformatsyy bankovskykh resursov: dyss. na soysk. nauchn. stepeny dokt. ekon. nauk: spets. 08.00.08 «Denhy, fynansy y kredyt». Sumy. 446.

Dovhan, Zh. M. (2008). Kapitalizatsiia bankivskoi systemy Ukrainy. Visnyk NBU. 11, 10-14.

Kornyliuk, R. V. (2012). Inozemni banky v Ukraini: vplyv ta rehuliuvannia : [monohrafiia]. K.: KNEU. 234.

Reverchuk, S. K. (2011). Bankovskii kapital v sisteme vosproizvodstva. Ekonomicheskaia teoriia i istoriia ekonomicheskoi mysli. 1, 14-18.

Gale, D. (2010). Capital Regulation and Risk Sharing. International Journal of Central Banking. 6 (4), $187-204$.

Greuning, H., Bratanovic, S. (2009). Analyzing Banking Risk: A Framework for Assessing Corporate Governance and Risk Management. World Bank Publications. 422.

Hancock, D., Lehnert, A., Passmore, W., Sherlund, S. (2006). The Competitive Effects of Risk-Based Bank Capital Regulation: An Example from U.S. Mortgage Markets . Federal Reserve Board. 50.

Kovalenko, V. V. (2013). Bankivske rehuliuvannia i nahliad: metodolohiia ta praktyka : [monohrafiia]. Odesa: Atlant. 492.

Naumenkova, S. (2015). Bazel I, II, III: rozvytok pidkhodiv dlia zmitsnennia rehuliatornoi osnovy. Visnyk Kyivskoho natsionalnoho universytetu imeni Tarasa Shevchenka. 12 (177), 39-47.

Khabiuk, O. (2008).Bankivske rehuliuvannia ta nahliad cherez pryzmu rekomendatsii Bazelskoho komitetu: [monohrafiia]. Ivano-Frankivsk: OIPPO; Sniatyn: PrutPrynt. 260.

Pro zatverdzhennia Instruktsii pro poriadok rehuliuvannia diialnosti bankiv v Ukraini: Postanova Pravlinnia NBU № 368 vid 28.08.2001. Access: http://zakon4.rada.gov.ua/laws/show/ z0841-01/print1433753775359538

Matviichuk, A. V. (2011) Shtuchnyi intelekt v ekonomitsi: neironni merezhi, nechitka lohika: [monohrafiia]. K.: KNEU. 439.

Plastun, O. L. (2014) Prohnozuvannia finansovykh rynkiv: suchasni kontseptsii ta novi pidkhody: [monohrafiia]. Sumy: DVNZ «UABS NBU». 397.

Cherniak, O. I., Zakharchenko, P. V. (2011) Prohnozuvannia sotsialno-ekonomichnykh protsesiv: suchasni pidkhody ta perspektyvy: [monohrafiia]. Berdiansk: Vydavnytstvo Tkachuk. 391. 